\title{
Colonization, succession and conservation: the invertebrates of Anak Krakatau, Indonesia, and contrast with Surtsey
}

\author{
Tim R. New \\ Department of Zoology \\ La Trobe University \\ Victoria, Australia 3086 \\ E-mail: t.new@1atrobe.edu.au
}

\begin{abstract}
Surveys of selected terrestrial invertebrates on Anak Krakatau, Indonesia, during the 1980s/1990s exemplify the variety of colonization and successional processes contributing to foundation of new ecological communities. Both aeolian and vegetation-based successions are important, but interpretation is hampered by lack of knowledge of the fauna of species-rich source areas in this tropical environment. Major disturbances from increased visitor numbers contaminate the natural processes, and volcanic activity is an ever-present influence. The monitoring and inventory studies needed to provide a sound basis for ecological management and conservation of this unique island, despite wide acknowledgement of its interest and significance, will be difficult to assure. The scenarios for documenting and conserving terrestrial invertebrates on Anak Krakatau and Surtsey are briefly compared.
\end{abstract}

\section{INTRODUCTION}

The processes of island colonization and early successions hold immense interest for ecologists, in helping to understand how complex interacting systems may be founded, and develop. Nowhere can these processes be demonstrated better than from studying those on newly formed volcanic islands, where there can be no debate about survival of organisms from previous periods and where those processes can be traced from their earliest pioneer stages. Parallels in successions and community development on isolated new volcanic islands have been discussed extensively, with several commentators (including Fridriksson \& Magnusson 1992, New, 2008, Thornton 1996, 2007) focusing on the similarities and differences between the ecological scenarios presented by Surtsey (subarctic: cool temperate) and Anak Krakatau ('Child of Krakatau', tropical). Reflecting these very different climates, these two small islands are likely to reach markedly different climax points. Anak Krakatau could potentially achieve tropical rainforest conditions, should time and absence of volcanic activity permit. The two islands show remarkable parallels in size (both around $2.5 \mathrm{~km}^{2}$ in area), topography (both around $200 \mathrm{~m}$ high during major survey periods, but with Anak Krakatau now considerably higher), ecological age, and distances from source biota - but, of course, also differ substantially in climate, the richness and knowledge levels of the source areas that may provide biota, the rates and extents of possible changes through succession, and the political and practical environments through which they can be protected and studied. 
These contrasting islands are fascinating and informative natural laboratories in which to explore some fundamental ecological themes, and in which speciation processes of resident populations have not yet developed. As a slight caveat to this, possible hybridization on the Krakatau archipelago of distinctive parental strains (such as of a few butterflies with distinct 'forms' either side of the Sunda Strait) from Sumatra and Java, the two main source areas, has led to consideration of this, and several putative 'subspecies' have been named. However, in reality in studying Anak Krakatau we are restricted to dealing with rapid recent ecological change rather than any longer term evolutionary changes or speciation. This is also so for the considerably less rich fauna on Surtsey, but there with the advantage that the potential donor faunas are well documented and of limited richness. The identities and likely origins of most invertebrates on Surtsey are unambiguous. Relative intensity of collecting on the Krakatau archipelago has perhaps disproportionately inflated impressions of endemism, because of lack of equivalent attention to progressively degraded source areas. Simply that particular taxa have been found only on one or more Krakatau islands is, perhaps, far more likely to reflect undercollecting elsewhere than endemism. In contrast, for example, the far older examples of the Hawaiian archipelago have generated enormous numbers of radiative taxa from founder colonizers, to constitute complex and wholly endemic suites of invertebrates and others. Hawaii is also a potent warning of the impacts of people, and of invasive species, on such isolated biotas, as a widespread context of conservation concern.

Invertebrates are the major components of animal diversity. They encompass enormous taxonomic and ecological variety, and govern many key ecosystem processes. Invertebrates are also major tools in leading to understanding of how such systems establish, become sustaining, and also vulnerable. This short overview draws on published information from selected invertebrate surveys on the Krakatau archipelago in the 1980s-1990s to indicate their values in documenting and interpreting early successional processes.

\section{ANAK KRAKATAU}

Following the massive eruption of Krakatau in August 1883, submarine volcanic activity continued in the caldera between the three residual islands

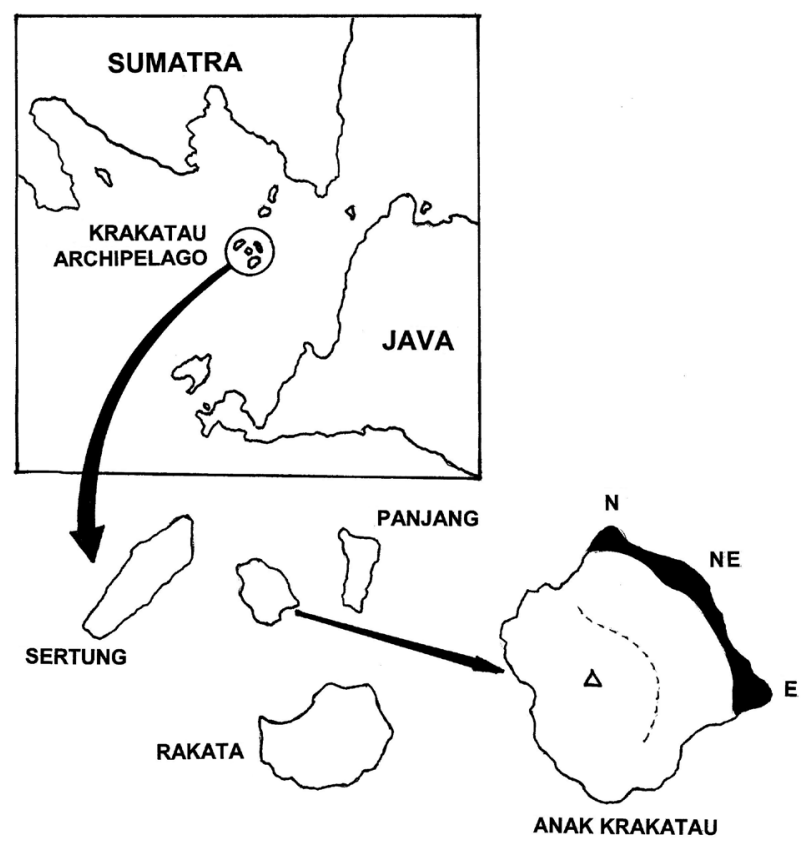

Figure 1. The Krakatau Archipelago, showing position in the Sunda Strait, the position of Anak Krakatau in the caldera surrounded by the three older islands left from the 1883 eruption (Sertung, Panjang, Rakata), and major features of Anak Krakatau ca 1990 (black, extent of vegetation along eastern coast with three main seral areas (Eastern Foreland, Northeastern Headland and Northern Foreland indicated by initial letters; dashed line, rim of outer crater; triangle, active crater).

of Rakata, Sertung and Panjang. Anak Krakatau emerged first from the sea in the centre of the caldera of the Krakatau archipelago, Sunda Strait, in 1927, but stabilised above water only in 1930 (Fig. 1). It has continued to increase in size, and is actively eruptive to the present.

There is continuing controversy over whether the whole communities there were truly extirpated by volcanic activity in 1952-1953 and damaged severely again in 1972 (van Borssum-Waalkes 1960, Partomihardjo etal.1993, Whittaker etal.,1989,1992), and Fosberg (1985) noted that the 1952 and 1972 eruptions were "two total or almost total sterilizations of Anak Krakatau'. Subsequent ecological studies have widely adopted that premise, and focused on successions since 1953, and the extent and ways in which they have been deflected by volcanic activity. In contrast, the vegetation on the three older islands (only 2-4 km distant) has proceeded for more than a century without such disruption. Unfortunately, however, and in marked contrast to the initiatives shown for Surtsey, Dammerman's (1948) plea that ecological developments on Anak Krakatau should 
be monitored carefully (so in part compensating for lack of such earlier systematic survey efforts for Krakatau from 1883) has not been adopted. No such coordination was possible, and information has accrued mainly through efforts of several independent research groups only from the early 1980s on. That work was facilitated immensely by the support of the Indonesian Institute of Science (LIPI: Lembaga Ilmu Pengetahuan Indonesia) in seeking to mark the centenary of the 1883 eruption. Outcomes of work by teams of scientists from Japan, the United Kingdom and Australia working with Indonesian scientists were partially assembled by Thornton $(1992,1996)$ and Tagawa (2005), with successional processes on the islands a predominant research theme. The general appearance of Anak Krakatau around that period is shown in Fig. 2. Despite the attractiveness of the concept that Anak Krakatau exhibits succession that closely parallels that occurring earlier on the other islands, this proposition remains controversial, because of the highly changed nature of source areas. Development on Anak Krakatau can draw from the well-developed communities on the nearby older islands, as well as from Sumatra and Java.

No systematic zoological surveys were made on Anak Krakatau for almost 30 years from 1952, so that critical early stages of colonization and succession have not been recorded. Since the mid1990s, more recent work by visiting biologists has become infrequent because of political difficulties and continuing volcanic activity. The ecological validity of surveys is also being distorted because the island is subjected to largely uncontrolled visitation by tourists and others, despite formal need for permits for landing access. The major data on successions and invertebrates have thus come largely

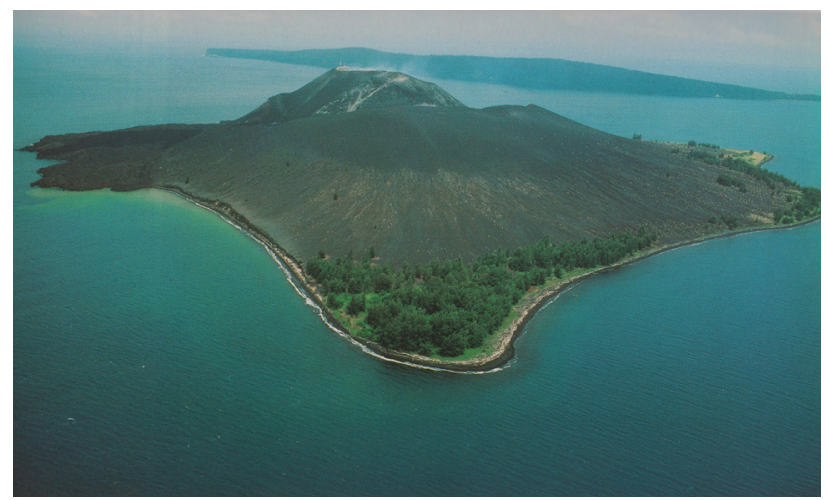

Figure 2. Anak Krakatau, from the east in 1985, looking on to developing Casuarina forest on the Eastern Foreland (Sertung in background). from work up to the early 1990s, by which time considerable anthropogenic disturbance was already evident. This 'ad hoc' accumulation of information differs fundamentally from the thorough systematic approach for Surtsey, but nevertheless illustrates some important and complex ecological themes based on temporal and spatial mosaics of vegetation, the variety of successional processes, and the trajectories being influenced by unpredictable disturbances.

\section{SUCCESSIONAL PROCESSES}

The major arrival and post-arrival processes relevant for invertebrate community development on Anak Krakatau are themselves diverse, and have been discussed extensively elsewhere, together with the likely filter effects that have occurred for some groups (New \& Thornton 1992, Thornton, 1996, 2007) - as examples, termites found there are wood nesters likely to have arrived in driftwood, and soil nesting taxa had not been found (Abe 1994); and most of the aculeate Hymenoptera recorded are not swarm movers, but disperse as solitary individuals (Yamane et al. 1992). Relatively informative analyses of Anak Krakatau terrestrial invertebrates in the context of those on the three older islands nearby and the mainland faunas are few, but encompass three main themes:

(1) inventories of particular taxonomic groups, notably terrestrial molluscs, soil nematodes, and a variety of arthropod orders of particular interest to individual expeditioners;

(2) the biases of modes of arrival and early succession; and

(3) progressive changes and development of assemblages and communities as succession proceeds, and placed in the wider context of vegetational development, vertebrate influences, and integration of mutualistic or other specific ecological associations.

These broad themes can be indicated using invertebrates, mainly insects, as examples to illustrate some of the more general findings and resulting concerns. In particular the transition from emphasising inventory surveys undertaken simply to enumerate taxa to clarifying faunal changes in relation to ecological processes and integration has wider importance in considering development and restoration. These processes are, however, founded in correlations of diversity, heterogeneity and turnover. 
Whilst turnover (involving losses of species) on Anak Krakatau is largely due to succession, more drastic losses may occur from volcanic activity. In contrast, losses from Surtsey may occur from progressive erosion (Svavarsdottir \& Walker 2009).

The major foci on natural processes involve (1) aeolian succession, with predators/scavengers depending on aerial fall-out for their food, and (2) the trajectories derived from initial colonizations of vegetation by herbivores as the foundation of foodwebs. They are augmented, and confused, by (3) anthropogenic influences and introductions that are extremely difficult to detect, monitor and differentiate from natural arrivals. Direct short visitations by tourists (both individuals and larger groups, such as from cruise ships), pumice-gatherers, fishermen and those seeking shelter from storms are frequent, and the debris from one of the world's busiest shipping lanes and from both Java and Sumatra assures continuing beach deposition of wood and other organic materials of unknown provenance. The major components that have been studied on Anak Krakatau over similar periods and are thus complementary in contributing to inventory listings, are:

(1) aeolian communities in bare ash and lava, with the predominant scavenger/predator being a small flightless cricket (Pteronemobius krakatau) and trapping demonstrating that at least several million arthropods are deposited as aerial fallout on the island each day (New \& Thornton 1988, Thornton et al. 1988);

(2) invertebrates associated with Saccharum clumps extending progressively as the pioneer colonizer of bare ash, and acting both as interception traps for aerial drift and foci for colonization as litter accumulates (Turner 1992);

(3) the invertebrate richness and biomass on Casuarina trees of different ages, as a temporal sequence from east (oldest) to north (youngest) along the coast, together with changes in some insect groups along this temporal sequence (Turner 1997); and

(4) the progressive development of mutualisms between figs (Ficus spp.) and fig wasps (Agaonidae) as the initial stages of secondary forest are reached (Compton et al., 1988).

All have been documented, as cited above, with wider synthesis by Thornton (1996), but none has been followed beyond these important initial stages to determine their later fate.

The general importance of prevegetation successions involving invertebrates feeding on allochthonous aeolian fallout is still novel to many ecologists, despite it being widespread on many kinds of substrate. Indeed, Hodkinson et al. (2002) proposed that it may be a general rule in primary community assembly, with roles including nutrient conservation and facilitating establishment of green plants through which more 'conventional' successions may proceed. The two main processes occur together on Anak Krakatau and, whilst largely separated in space, the participants are brought together by, for example, Saccharum tussocks. As elsewhere, the basic information was derived initially from surveys to collect, diagnose and enumerate the species present, using a variety of sampling techniques, but with surveys necessarily limited in duration and seasonal coverage. Interpretation has inevitably been uneven - as in many (most!) invertebrate surveys from the tropics, only selected groups can be appraised realistically at the species (or morphospecies) level. Attempts to sample the founder faunas on either side of the Sunda Strait and on the three older islands of the archipelago have been valiant but, again, are highly incomplete. Likewise, the roles of the island of Sebesi, to the north, as a 'stepping stone' for colonisation have been suggested repeatedly. It is also generally unknown whether colonists arrived from the older islands or from further afield, and how their incidence may be facilitated by the very short distances involved. One instructive example is the antlion Myrmeleon frontalis (Neuroptera, Myrmeleontidae), found on the three older islands, but not Anak Krakatau in the early 1980s (New \& Sudarman 1988). It was found there in 1986, initially under the shelter of the small coastal hut built in that year, from where it expanded to frequent clumps of wild sugarcane (Saccharum spontaneum) on the adjacent ash cone (Turner 1992).

Perhaps the most informative data have come from the fact that the seral vegetation stages on Anak Krakatau are well-defined, with the major vegetated areas over the main sampling periods comprising three distinct but intergrading seral ages following a similar trajectory along the east-north shoreline. These, termed the Eastern Foreland (oldest), Northeastern Headland (intermediate) and Northern Foreland (youngest) could thus be considered 

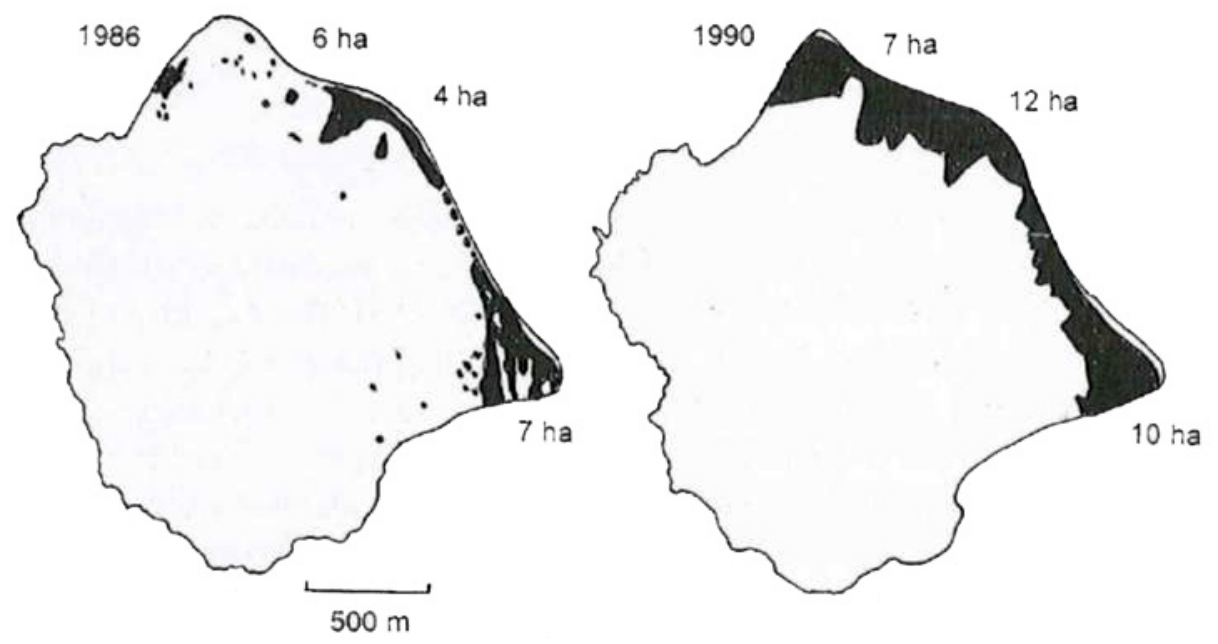

Figure 3. Changes in extent and continuity of vegetation from 1986 to 1990: vegetation in black, approximate areas given in hectares (from Thornton et al. 1992). separately, but as a temporal sequence of decreasing variety and complexity. This enables the presence of successional mosaics, and probably originated from the differentially damaging eruptions of 1972/1973 (Thornton 1996). Nevertheless, changes were rapid (Fig. 3). In 1984, little vegetation occurred on the Northern Foreland, and the most advanced Casuarina equisetifolia woodland on the Eastern Foreland, was open with substantial pioneer Ischaemum and Ipomoea understorey. By 1990, the latter area was far more mature, and Casuarina also wellestablished to the north. The transition from sparse Saccharum grassland to definable Casuarina forest was described by Suzuki et al. (1995). Saccharum grass clumps extended progressively up the outer ash cone as the major pioneer species away from the coast (Fig. 4). At the time of our work in the 1980s, the vegetated area of Anak Krakatau was only about 17 ha of the total island area of about 235 ha, and the coastal length available for arrivals by sea was 7-8 km. Rafting has clearly been important for such arrivals, with seeds of numerous plants (propagules of 66 taxa in 1990-91, with only 30 of these known from elsewhere in the archipelago: Partomihardjo et al. 1993) found in strand surveys, and logs and large complex mats of vegetation a clearly viable vehicle

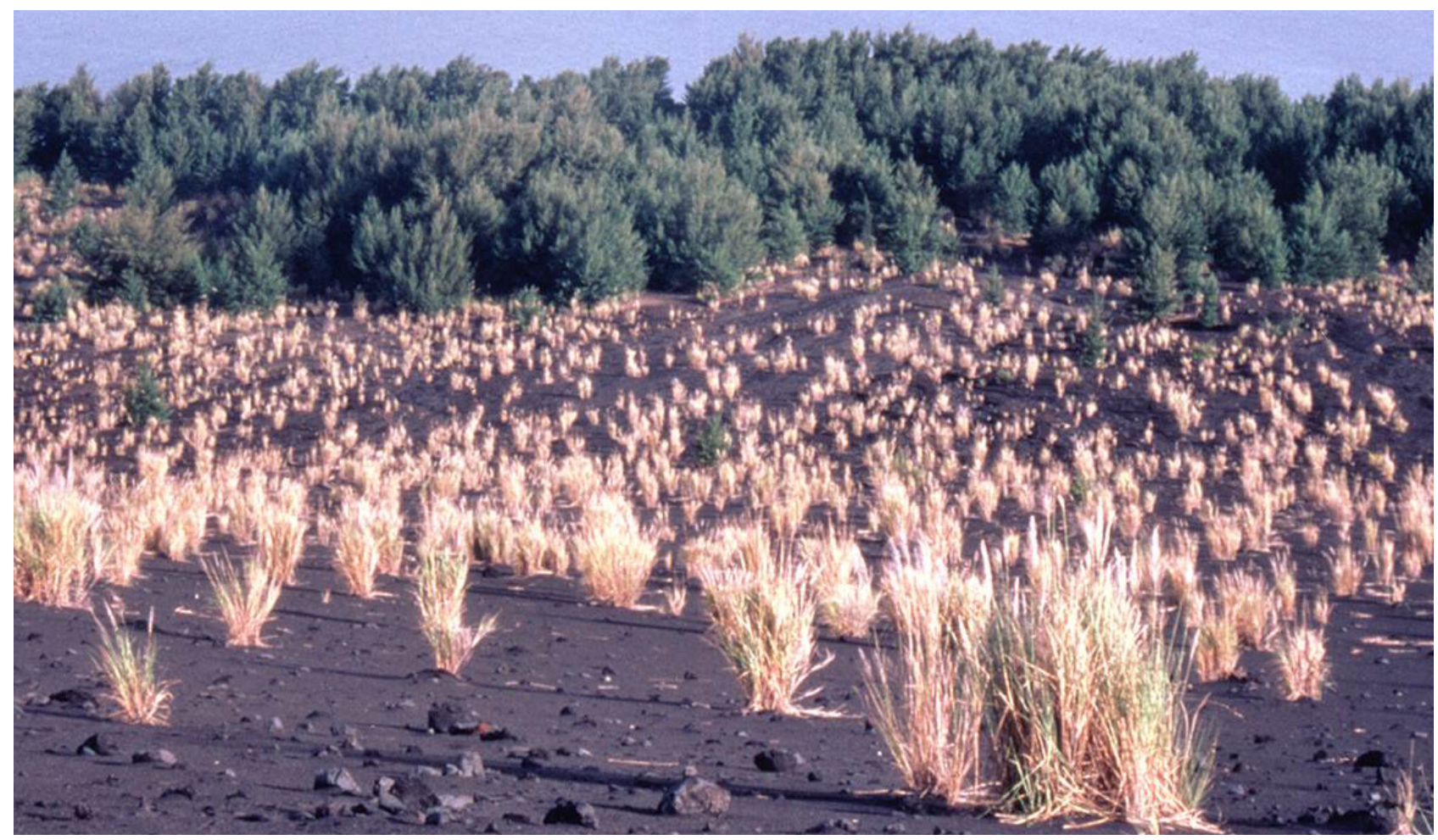

Figure 4. The spread of Saccharum spontaneum tussocks up the bare volcanic slope above the Eastern Foreland, 1993. 
for a variety of biota to arrive - one vegetation mat noted during our visits extended to around $20 \mathrm{~m}^{2}$ and included 3-4 $\mathrm{m}$ high palm trees with green foliage.

These seral vegetation changes can be correlated with changes in someinvertebrate groups. Of the betterdocumented herbivore groups, the butterflies (with most taxa recognizable consistently, and a relatively strong regional picture of distribution and biology), are by far the most comprehensively surveyed and have been enumerated by most expeditions. Richness correlated strongly with vegetation life forms. Of the 44 species recorded in 1990, 18 had apparently arrived since 1986 (New \& Thornton 1992a,b), and several were unknown from the older three islands. The greatest richness ( 31 species, of which 26 were considered locally resident: New 2008) occurred on the most mature East Foreland area, with progressive attenuation northward.

Whilst study of some groups of invertebrates (such as molluscs and soil nematodes: Smith\& Djajasasmita 1988, Winoto Suatmadji et al. 1988) implies that the Anak Krakatau fauna is an impoverished subset of those taxa found on the older islands, Anak has also yielded numerous species that are (1) not known from the older islands or (2) may now depend on early successional stages, such as open grasslands, not now present there, so constituting an 'ecological rescue' effect. Several grassland butterflies, for example, can be supported only on Anak Krakatau where these environments occur. Some of those species were found in earlier surveys on other parts of the archipelago, where their requirements are no longer available. As demonstrated on the older islands, the trajectories on Anak Krakatau, if undisturbed, are likely to engender forest environments of greater complexity and richness within a few decades. In part, this will reflect greater opportunities for interactions with the biota of those islands, with the Anak environment progressively more hospitable to such local colonizers and, perhaps, the 'filter effect' for arrivals reducing as the islands converge in character.

Developments on Surtsey are rather more constrained but also have been monitored more intensively from the earliest stages, so that changes are documented well. Studies of Surtsey invertebrates commenced in 1965 and proceeded through regular surveys until 1984. After a more irregular period, yearly visits re-commenced in 2002 (Olafsson \&Ingimarsdottir 2009), concentrating on a standard season of four days in July. One valuable clue to understanding has been to include trapping close to access points, to attempt to detect human impacts. Visitors to Anak Krakatau also have limited access sites. These are mainly on the eastern beaches adjacent to the most complex vegetation systems, with a few access tracks facilitating tourist walks to the interior and, for many people, a scramble to the rim of the outer cone or the summit area. No regular surveys that parallel those on Surtsey have been formalized on Anak Krakatau, and traits such as the entry of the antlion noted earlier are found fortuitously. Another artifact for some years was a small concrete-lined rainwater-gathering trough constructed near the main landing beach of Anak Krakatau, which was the foundation for the only freshwater community on the island (Thornton \& New 1988b).

In essence, invertebrate surveys on Anak Krakatau have been sporadic, opportunistic and almost wholly by non-Indonesian scientists.

\section{DISCUSSION}

The basic successions noted above, and the relatively low species diversity across a variety of taxonomic and trophic invertebrate groups on Anak Krakatau, presented a substantial opportunity to elucidate some key elements of tropical ecology. The chances of undertaking those studies properly as undisturbed natural processes, probably already past, depend on continued monitoring and effective conservation through control of human interference and impacts. This seems unlikely to occur. The chances of effective conservation of Anak Krakatau at levels approaching those in place for Surtsey, are very low.

At one level, Anak Krakatau is regarded as important, a source of wonder, pride - and tempered with trepidation of what it might portend. As a designated World Heritage Site (from 1992) a duty of care is mandated, but without dedicated personnel and greater controls on tourism and other visitations, this is difficult to pursue. Likewise, the regular systematic surveys needed to follow further the ecological trajectories so far discerned are unlikely to come primarily from within Indonesia.

Many visitors to the island during our surveys were motivated by the volcano and the 'romanticism' of 'Krakatau'. Some had little appreciation of the wider environmental significance of Anak Krakatau, and did not hesitate to leave litter and debris. It 
seems that without greater awareness and regulation of access, any conservation is unlikely to proceed beyond 'paper commitment'. Recent nomination of Anak Krakatau to become a UNESCO Geopark (2012), by the Lampung Provincial Administration (Sumatra), is motivated strongly by desire to increase tourism for Lampung, following the submission guideline that such a park should be 'a large enough area for it to secure local economic and cultural development (particularly through tourism).' Strong community support and local involvement are integral to the assessment criteria. Clearly, increased tourism and visitations are anticipated, and likely to be encouraged, to the substantial benefit of local economies.

However, 'restricted access is extremely valuable in the study of primary sucession', and one of the greatest advantages for Surtsey is simply this restricted and regulated visitation, emphasized by Svavarsdottir \& Walker (2009, as in the above quotation). Even on Surtsey, they noted that any visit causes some disturbance. On Anak Krakatau, disturbance is frequent, unpredictable but certain, varied and with largely undocumented impacts. Unlike Surtsey, where ecological progression under regulated and monitored conditions seems assured and Hawaii, with more complex environments heavily contaminated by alien species and resident human populations, Anak Krakatau is to some extent a self-generating environment where a progressively complex suite of temporal mosaic substrates and vegetation continues to be generated. Each has its future at the whim of continuing volcanism (Fig. 5), and potential for planning its practical long-term conservation has limits. The underlying desirability of facilitating chances of natural development and evolution depends on minimizing human intrusions and disturbance, but also assuring sufficient monitoring and survey to interpret changes sensibly. Permanent survey plots, so important in successional interpretations (del Moral 2009), have not been established on Anak Krakatau. Such plots were, however, established on the three older Krakatau islands in 1989 and have yielded valuable information on changes in vegetation (Whittaker et al. 1999).

Volcanic activity may be both a great benefit and a severe threat to the biota present. In the short term, low level activity is a deterrent to some visitation and may thus be a considerable protection against human disturbance with little impact on other biota. In the longer term, increased volcanic activity may destroy all that is present. It is believed by some that Anak Krakatau's recent sustained activity may be a prelude to a far more devastating eruption - perhaps within the next few decades, and possibly equivalent to the 1883 episode in intensity and impact. Information on the island's ecology will then become of historical interest but may also constitute a comparative template for some future equivalent study, much as information in Dammerman (1948) on the colonization of the older Krakatau islands post- 1883 stimulated considerable debate.

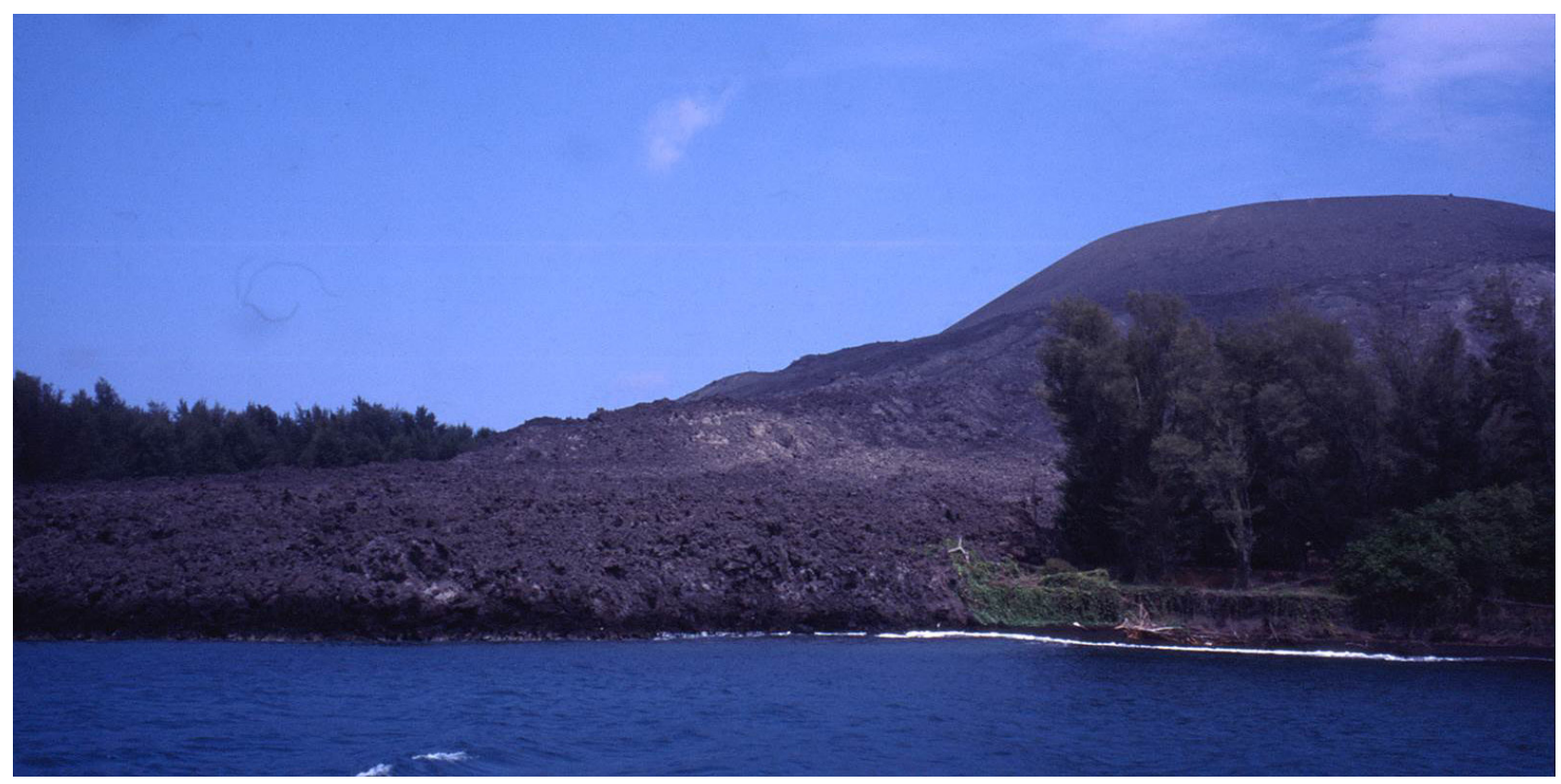

Figure 5. Interruption of vegetation between Northeastern Headland and Northern Foreland by volcanic lava flow of 1993. 
More broadly, the current lack of attention to development of the unique environment of Anak Krakatau reflects considerations of wider protected areas in Indonesia. The impressive declared Protected Areas system of Indonesia, with its considerable extent and variety, does not extend fully from paper to practice. Most National Parks receive little practical protection, even when inhabited by charismatic large mammals, and most such areas on the densely populated islands of Java and Sumatra continue to be exploited by forest clearance and kebun gardening systems - leading to predictions such as Sumatra being likely to lose all of its lowland primary forest (Jepson et al. 2001). The only more secure areas are likely to be those that are either at high elevations or otherwise remote, and are difficult to access. Mainland Ujung Kulon (as relatively remote) falls into this 'lower risk' category whilst, in contrast, the Krakatau archipelago (previously part of the same National Park) appears increasingly vulnerable.

Whatever basic ecological information can be gleaned, the scientific case for effective conservation of the Krakatau archipelago rests largely on its unique status as '... an example of the natural recovery of lowland tropical forest from the most extreme natural disturbances' (Thornton 1996), even as nearby forests either side of the Sunda Strait succumb to human pressures. Understanding successions, based on sound documentation of changes in composition and diversity of invertebrate assemblages, and protecting their capacity for continued ecological and evolutionary development, is fundamental to that case.

\section{ACKNOWLEDGEMENTS}

This paper is based on a keynote talk given at the Surtsey $50^{\text {th }}$ Anniversary Conference, Reykjavik, August 2013. I am very grateful to Dr Borgthor Magnusson and his colleagues for the invitation to participate and the financial aid received through the Surtsey Research Society. My visits to Krakatau were undertaken as a member of the team led by the late Professor Ian Thornton: his friendship over several decades has lasting influence.

\section{References}

Abe, T. 1984. Colonisation of the Krakatau Islands by termites (Insecta; Isoptera). Physiol. Ecol., Japan, 21, 63-85.

Compton, S.G., I.W.B.Thornton, T.R. New \& L. Underhill 1988. The colonization of the Krakatau Islands by fig wasps and other chalcids (Hymenoptera: Chalcidoidea). Phil. Trans. R. Soc. Lond., B 332, 459-470.

Dammerman, K.W. 1948.The fauna of Krakatau 18831933. Verhandlungen Koninlijk Nederlandsche Akademie Wetenschaft 44, 1-594.

del Moral, R. 2009. Primary succession on Mount St Helens, with reference to Surtsey. Surtsey Research 12, 153-157.

Fosberg F.R. (1985) Botanical visits to Krakatoa in 1958 and 1963. Atoll Res. Bull., 292, 39-45.

Fridriksson, S. \& B. Magnusson 1992.Development of the ecosystem on Surtsey with reference to Anak Krakatau. GeoJournal, 28, 287-291.

Hodkinson, I.D., N.R. Webb \& S.J. Coulson 2002. Primary community assembly on land - the missing stages: why are the heterotrophic organisms always there first? J. Ecol., 90, 569-577.

Jepson, P., J.K. Jarvie, K. MacKinnon \& K.A. Monk 2001 The end for Indonesia's lowland forests? Science 292, 859-861.

New, T.R. 2008 Insect conservation in early succession on islands: lessons from Surtsey, Iceland, and the Krakatau Archipelago, Indonesia. J. Insect Conserv., 12, 307-312.

New, T.R. \& H.K. Sudarman 1988 Neuroptera (Insecta) of the Krakatau Islands, Indonesia. Phil. Trans. R. Soc. Lond, B 332, 413-426.

New, T.R. \& I.W.B. Thornton 1988 A pre-vegetation population of crickets subsisting on allochthonous aeolian debris on Anak Krakatau. Phil. Trans. R. Soc. Lond., B 332, 481-485.

New, T.R. \& I.W.B. Thornton 1992a Colonisation of the Krakatau islands by invertebrates. GeoJournal, 28, 219-224.

New, T.R. \& I.W.B. Thornton 1992b The butterflies of Anak Krakatau, Indonesia: faunal development in early succession. J. Lepidopt. Soc., 46, 83-86.

Olafsson, E. \& M. Ingimarsdottir 2009 The land-invertebrate fauna on Surtsey during 2002-2006. Surtsey Res., 12, 113-128.

Partomihardjo, T., E. Mirmanto, S. Riswan \& E. Suzuki 1993 Drift fruit and seeds on Anak Krakatau beaches, Indonesia. Tropics, 2, 143-256.

Smith, B.J. \& M. Djajasasmita 1988 The land molluscs of the Krakatau Islands, Indonesia. Phil. Trans. R. Soc. Lond., B 332, 379-400.

Suzuki, E., T.Partomihardjo \& E. Turmudi 1995 A ten-year succession of Saccharum spontaneum and Casuarina equisetifolia vegetations on Anak Krakatau, Indonesia. Tropics, 4, 127-131.

Svavarsdottir, K. \& L.R. Walker 2009 The value of Surtsey for ecological research. Surtsey Res., 12, 149-151.

Tagawa, H. (comp.) 2005 The Krakataus: change in a century since catastrophic eruption in 1883. Kagoshima.

Thornton, I.W.B. (ed.) 1992 Krakatau - a century of change. GeoJournal, 28, 84-302.

Thornton, I. 1996 Krakatau; the destruction and reassembly of an island ecosystem. Harvard University Press, Boston, Mass.

Thornton, I. (ed. New, T.) 2007 Island colonization: the origin and 
development of island communities. Cambridge University Press, Cambridge.

Thornton, I.W.B. \& T.R. New 1988a Krakatau invertebrates: the 1980s fauna in the context of a century of colonization. Phil. Trans. R. Soc. Lond., B 332, 493-522.

Thornton, I.W.B. \& T.R. New 1988b Freshwater communities on the Krakatau Islands. Phil. Trans. R. Soc. Lond., B 332, 487492.

Thornton, I.W.B., T.R. New, D.A. McLaren, H.K. Sudarman \& P.J. Vaughan 1988 Air-borne arthropod fallout on Anak Krakatau and a possible pre-vegetation pioneer community. Phil. Trans. R. Soc. Lond., B 332, 471-479.

Thornton, I.W.B., S.A.Ward, R.A. Zann \& T.R.New 1992 Anak Krakatau: a colonization model within a colonization model? GeoJournal, 28, 271-286.

Turner, B.D. 1992 The colonisation of Anak Krakatau: interactions between wild sugar cane, Saccharum spontaneum, and the antlion Myrmeleon frontalis. J. Trop. Ecol., 8, 435-449.

Turner, B.D. 1997 Patterns of change in arthropod biodiversity living on Casuarina equisetifolia, an early successional tree species on the island of Anak Krakatau, Indonesia. Trop. Biodiv., 4, 241-257.

van Borrsum-Waalkes, J. 1960 Botanical observations on the Krakatau Islands in 1951 and 1952. Annales Bogoriensis 4, 5-63.

Whittaker, R. J., M.B. Bush \& K. Richards 1989 Plant recolonisation and vegetation succession on the Krakatau Islands, Indonesia. Ecol. Monogr., 59, 59-123.

Whittaker, R. J., M.B. Bush, T. Partomihardjo, N.M. Asquith \& K. Richards 1992 Ecological aspects of plant colonization of the Krakatau Islands GeoJournal, 28, 201-211.

Whittaker, R.J., T. Partomihardjo \& S.H. Jones 1999 Interesting times on Krakatau: stand dynamics in the 1990s. Phil. Trans. R. Soc. Lond., B 354, 1857-1867.

Winoto Suatmadji, R., A. Coomans, F. Rashid, E. Geraert \& D.A. McLaren 1988 nematodes of the Krakatau Archipelago, Indonesia: a preliminary overview. Phil. Trans. R. Soc. Lond., B 332, 369-378.

Yamane, S., T. Abe \& J. Yukawa 1992 Recolonisation of the Krakataus by Hymenoptera and Isoptera (Insecta). GeoJournal, $28,213-218$. 